\title{
Effects of Sanitizers on the Control of Alternaria sp. Fungus for 'Palmer' Mango Conservation
}

\author{
E. P. da Silva ${ }^{1}$, A. Figueiredo Neto ${ }^{1}$, J. C. Silva ${ }^{1}$, V. P. Donzeli ${ }^{1}$, M. S. Costa $^{2}$, J. D. S. Costa ${ }^{2}$ \\ \& R. M. C. Figueiredo ${ }^{3}$ \\ ${ }^{1}$ Collegiate of Agricultural and Environmental Engineering, Universidade Federal do Vale do São Francisco, \\ Juazeiro, Bahia State, Brazil \\ ${ }^{2}$ Graduate Program in Agricultural Engineering, Universidade Federal de Campina Grande, Campina Grande, \\ Paraiba State, Brazil \\ ${ }^{3}$ Agricultural Research Company, Countryside, PE, Brazil \\ Correspondence: E. P. Silva, Collegiate of Agricultural and Environmental Engineering, Universidade Federal do \\ Vale do São Francisco, Av. Antônio C. Magalhães, 510-Country Club, Juazeiro, BA, 48902-300, Brazil. Tel: \\ 55-74-2102-7609. E-mail: edson_psilva10@hotmail.com; acacio.figueiredo@univasf.edu.br
}

$\begin{array}{lc}\text { Received: June 20, 2020 } & \text { Accepted: July 27, } 2020 \quad \text { Online Published: August 15, } 2020 \\ \text { doi:10.5539/jas.v12n9p216 } & \text { URL: https://doi.org/10.5539/jas.v12n9p216 }\end{array}$

The research is financed by Fundação de Amparo à Pesquisa do Estado da Bahia.

\begin{abstract}
One of the main problems faced by mango growers in the San Francisco Valley, Brazil, is caused by fungi. Among them, the genus Alternaria, Lasodiploida and Colletotrichum stand out. Sanitization methods have been studied in order to control the proliferation of these microorganisms and increase the shelf life of the fruits. Thus, two methods of sanitization were evaluated: Ozone and chlorine dioxide, in the control of fungi of the genus Alternaria and in the increase of post-harvest quality of Palmer mango fruits. We used a $3 \times 5$ factorial design with three treatments applied to fruits previously inoculated with fungi, five evaluation periods and five replications, totaling 75 experimental units. The treatments consisted of ozonated water at $3 \mathrm{ppm}$, chlorine dioxide at $12 \mathrm{ppm}$, and a control without sanitization. We noted the full development of fungi from the 10th day after contamination, more significantly for the control and to a lesser extent for the treatment with ozone. The methods of conservation with ozone and chlorine dioxide proved efficient in the conservation of fruits. The treatment with chlorine dioxide shows a significant efficiency in the control of penetration of fungi of the genus Alternaria inside the fruits.
\end{abstract}

Keywords: post harvest, Mangifera indica, microrganisms, shelf life

\section{Introduction}

Among the main mango producers in Brazil, the San Francisco Valley stands out not only in quantity, but also in quality of the fruits produced. It is one of the main centers of agricultural production and guarantees the growth and development of fruit production in the region (Vidal \& Ximenes, 2016).

It is known that fungi have a great importance for mango cultivation. In addition to causing losses in post-harvest (fruit rot, shorter shelf life, loss of organoleptic quality, etc.), also cause losses in the field. It is a limiting factor for fruit quality (Oliveira et al., 2016).

In this sense, techniques have been sought to minimize the appearance of microorganisms during the processing and transportation phases, in addition to maintaining the physical and chemical characteristics of mango. According to Mathew et al. (2018), in the absence of practical technologies that provide a necessary step to eliminate pathogens, mango producers rely on the use of disinfectants dissolved in washing water to increase fruit safety. In fact, studies have shown that the incorporation of effective disinfectants into washing water can control pathogens in water and, thus, prevent their internalization (Penteado et al., 2004; Soto et al., 2007; Mathew, 2019).

Among such post-harvest treatment techniques, ozonation has been considered as one of the main conservation methods. According to Horvitz and Cantalejo (2014), the use of ozone at the post-harvest stage allows the 
conservation of products with high quality parameters of physical and microbiological attributes, since it has a high oxidation potential and can act both in the air as in water.

Aafia et al. (2018) reported that the use of ozone gas increases the storage time of fruits (apple, peach, mango, banana, among others), in addition to promoting the maintenance of the physicochemical parameters of the fruits Oliveira et al. (2016) verified ozone sanitizing action for the control of Fusarium pallidoroseum associated with refrigeration.

In addition, ozone is highly effective in neutralizing ethylene (Tran et al., 2013), a hormone responsible for the maturation process and the subsequent senescence. It is also a chemically reactive substance, exerting significant antibiotic activity on a variety of deterioration organisms, including fungi and bacteria (Carletti et al., 2013), which makes ozonation an alternative to extending the storage time of mango.

Glowacz and Rees (2016) emphasized the need for a prior assessment of quantities and methods of application of ozone before its commercial use. The effects of ozone on fruit physiology and quality may vary according to type, chemical composition, maturation status, and applied dose (time and concentration of sanitizer).

On the other hand, chlorine dioxide $\left(\mathrm{ClO}_{2}\right)$ stands out as an alternative because, although it is derived from chlorine, it is a stable, non-reactive molecule that generates an insignificant quantity of byproducts and acts as a powerful biocide. According to Conteras-Soto et al. (2018), its use is safe and meets the regulatory standards established for the processing of mango.

Conteras-Soto et al. (2019) reported a faster deteriorating action of chlorine dioxide in mangoes compared to sodium hypochlorite. Praguer et al. (2018) observed that the application of aqueous $\mathrm{ClO}_{2}$ effectively reduces the counts of natural or inoculated microorganisms.

Given the impact of fungi in mango cultivation, it is necessary to evaluate and compare these two treatment methods, to identify their efficiency in control external and internal microorganisms, as well as to preserve the post-harvest quality of fruits during the storage period.

\section{Method}

The experiment was conducted at the Agricultural Products Storage Laboratory (LAPA) of the Federal University of Vale do São Francisco, located in the city of Juazeiro, Bahia, Brazil. We used export-type fruits of the variety 'Palmer.' They were collected in the packing house of the Special Fruit farm, located on the margins of the Juazeiro-Curaçá Highway, km 18, Mandacaru, Juazeiro, Bahia, Brazil.

\subsection{Experimental Design}

The treatments consisted of ozonated water at $3 \mathrm{ppm}$, chlorine dioxide at $12 \mathrm{ppm}$, and a control without sanitization. It should be noted that such concentrations were defined according to those used in the region and followed the manufacturer's recommendations. We used a $3 \times 5$ factorial design with three treatments, five evaluation periods and five replications, totaling 75 experimental units. Each experimental unit represented by a single fruit.

\subsection{Inoculation}

After collection, we selected the fruits and inoculated them with colonies of fungi of the genus Alternaria sp. The fungus inoculation was carried out at the Microbiology Laboratory of the Federal University of San Francisco Valley in fruits previously washed with deionized water and neutral detergent. The isolated colonies were transferred to the region of the fruit pendulum using a sterile swab. Then, the inoculated fruits were placed in container boxes, moistened with cotton, and wrapped in plastic bags for 48 hours to provide favorable conditions of temperature and humidity for the germination of fungi. After this period, the treatments were performed.

\subsection{Treatments}

The fruits were separated into three groups, each with 25 fruits, in order to determine the respective treatments. Part of the fruits was treated with ozone. They were submerged in ozonized water at $3 \mathrm{ppm}$. Another part was treated with chlorine dioxide, which were similarly submerged in chlorinated water at $12 \mathrm{ppm}$ for 20 minutes for both treatments seeking to simulate the conditions of packing houses in the region. A third part of the fruits was reserved for the control (without treatment).

After treatment, the fruits were placed on a bench under refrigeration at $20 \pm 2{ }^{\circ} \mathrm{C}$ for twenty days, and periodic evaluations were carried out every five days. The fruits of the control group were also submitted to the same storage condition and evaluated at the same periodicity as the others. 


\subsection{Analysis of Microbial Development}

The analysis of the microbial development took place from the recording of images of the external and internal region of the peduncle, separated with a steel blade, and observed under a microscopic magnifying glass, Opton ${ }^{\circledR}$, Model TIM-30, with 10x zoom, through which it was possible to visually evaluate the evolution or inhibition of the fungus in the fruit at the time. Scores were adopted for each development stage according to the Figure 1.

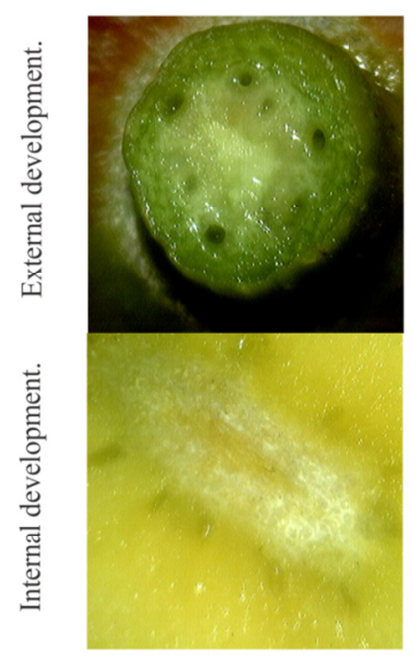

Score 0 - Internal and external development not visible.

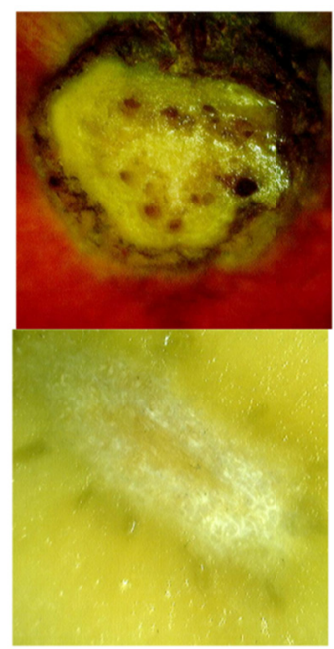

Score 1 - low development in the external region and not visible in the internal region of the fruits.

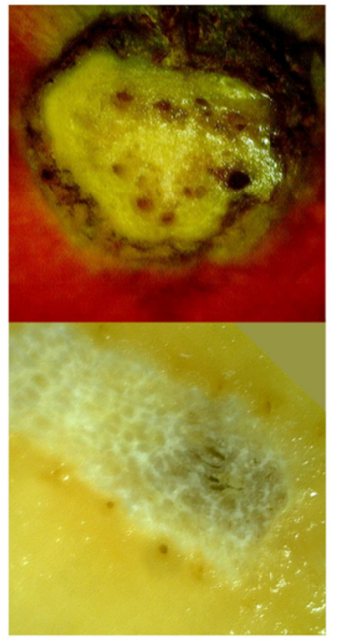

Score 2 - Intense development in the outer region of the fruit and low in the inner region.

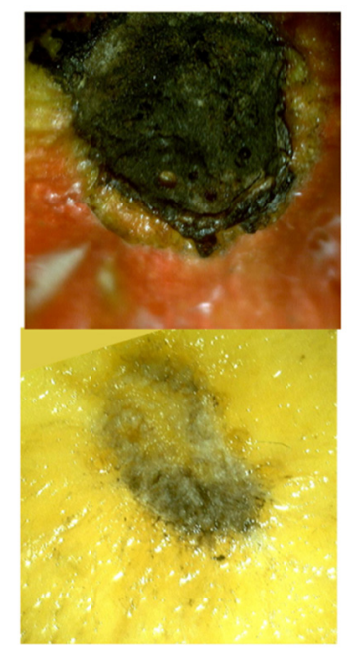

Score 3 - Intense development in the external and internal regions of the fruit.

Figure 1. Score adopted for each stage of fungal development during the storage period, being: 0 for internal and external development not visible; 1 for low development in the external region of the fruits and not visible in the internal region; 2 for intense development in the external region of the fruit and low in the internal region and 3 for intense development in the external and internal regions of the fruit

\subsection{Post-Harvest Analysis}

We also analyzed parameters related to post-harvest, such as mass loss (determined using a semi-analytical balance (Bell Engineering ${ }^{\circledR}$ with accuracy of $0.1 \mathrm{~g}$ ) penetration resistance (firmness, using a Rex durometer DD-4® digital penetrometer), titratable acidity (measured using the titration method with $0.1 \mathrm{M}$ sodium hydroxide), soluble solids contents (determined by direct reading on an Abbe Hanna ${ }^{\circledR}$ digital refractometer with a scale in ${ }^{\circ}$ Brix), absorbance difference index (AD, obtained through a portable spectrophotometer, DA-meter ${ }^{\circledR}$; estimated by the difference between absorbance values measured at $670 \mathrm{~nm}$ and $720 \mathrm{~nm}$; Noferini et al., 2009; close to the peak of chlorophyll a absorption, measured on both sides of each fruit), and skin color and pulp color (both determined using a Minolta CR 700® colorimeter spectrophotometer with the Cielab color system, obtaining the values of $\mathrm{L}^{*}, \mathrm{a}^{*}$ and $\mathrm{b}^{*}$, where $\mathrm{L}^{*}$ is luminosity, $\mathrm{a}^{*}$ is the transition from green $\left(-\mathrm{a}^{*}\right)$ to red $\left(+\mathrm{a}^{*}\right)$, and $b^{*}$ is the transition from blue $\left(-b^{*}\right)$ to yellow $\left.\left(+b^{*}\right)\right)$.

\subsection{Statistical Analysis}

After the analyses, the data were tabulated and treated statistically. Data were submitted to analysis of variance to diagnose significant effects between storage times and concentrations, respectively, using the software SigmaPlot ${ }^{\circledR}$ (Systat software inc., UK). The treatments were compared by Tukey test at $5 \%$ probability. In addition, regression analysis was performed for the variables analyzed over time.

\section{Results and Discussions}

We noted the full development of fungi from the 10th day after contamination, more significantly for the control and to a lesser extent for the treatment with ozone. From then on, in all evaluated periods, we noted that, in fruits 
treated with ozone, the penetration of the fungus inside the fruit occurred with less intensity compared to the control and fruits treated with chlorine (Figure 2).

\section{Control}
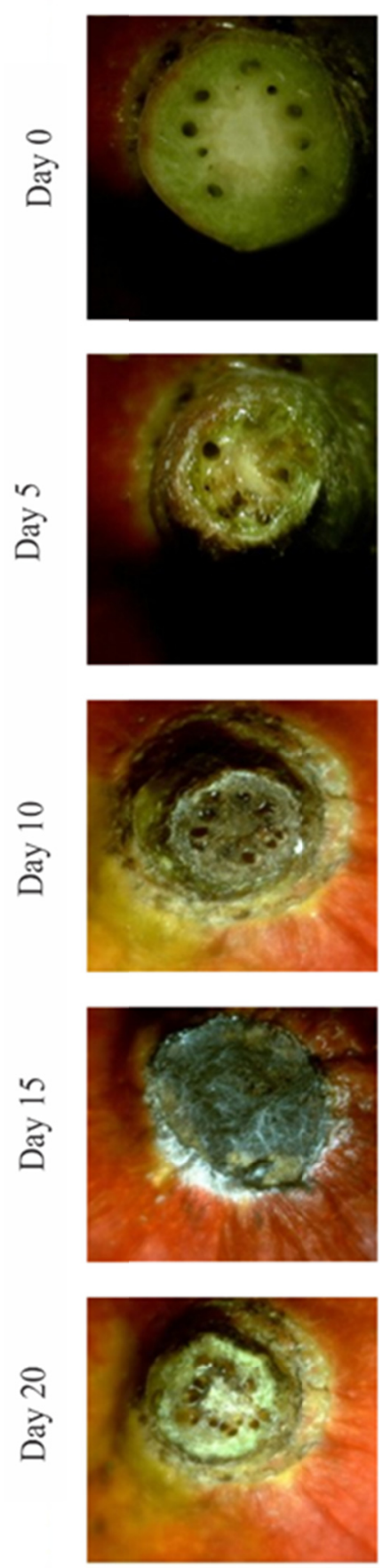

Ozone
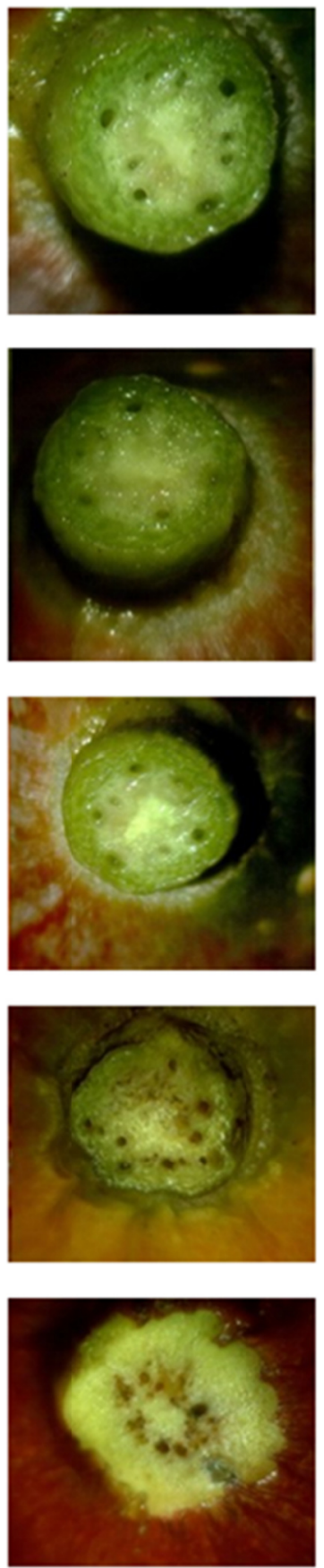

\section{Chlorine Dioxide}
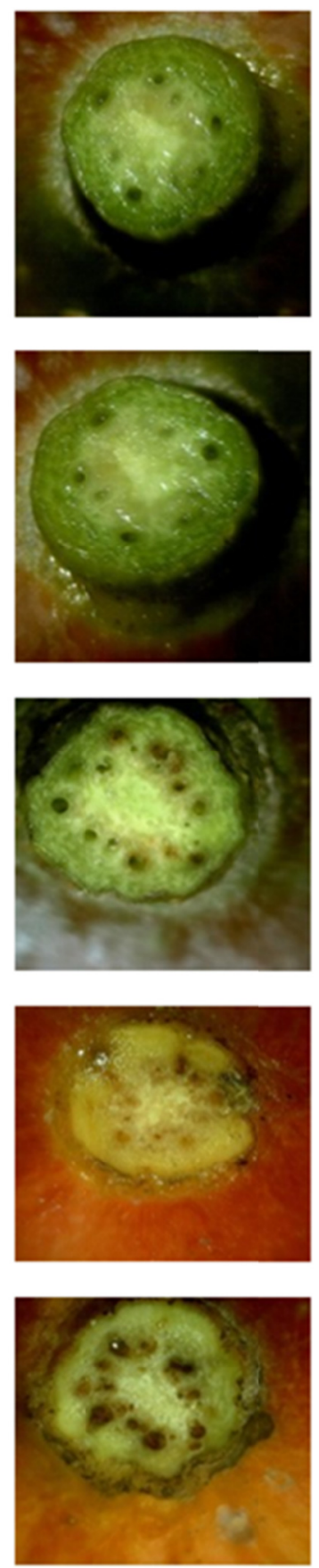

Figure 2. External growth of fungi of the genus Alternaria sp. in mango fruits subjected to three treatments (control, ozone, and chlorine dioxide) during 20 days of storage

At the end of the observation period (20 days), the untreated fruits (control) showed a greater microbiological development compared to treated fruits. Ong et al. (2013) corroborates this. The authors observed that the papaya fruits treated with ozone showed inhibition of fungal growth, when compared with the control. 
It should be noted that, due to the ideal conditions provided to fungi of Alternaria sp. at the beginning of the experiment, that is, the direct application of the fungus on the peduncle, the supply of temperature and humidity for its development and the two-day interval between inoculation and treatment caused the appearance of fungi on the external region of treated and untreated fruits.

We could measure the efficiency of treatments through images of the external part (Figure 1) and the internal part of fruits (Figure 3), which showed the inhibiting power to or the delay sanitizers cause in penetrating microorganisms into fruits.
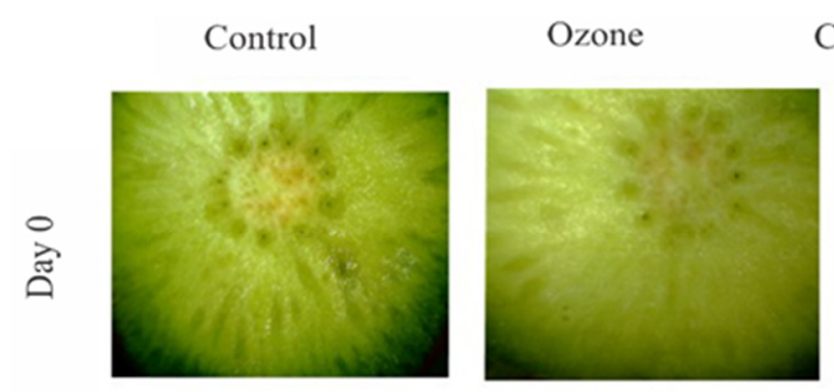

\section{Chlorine Dioxide}
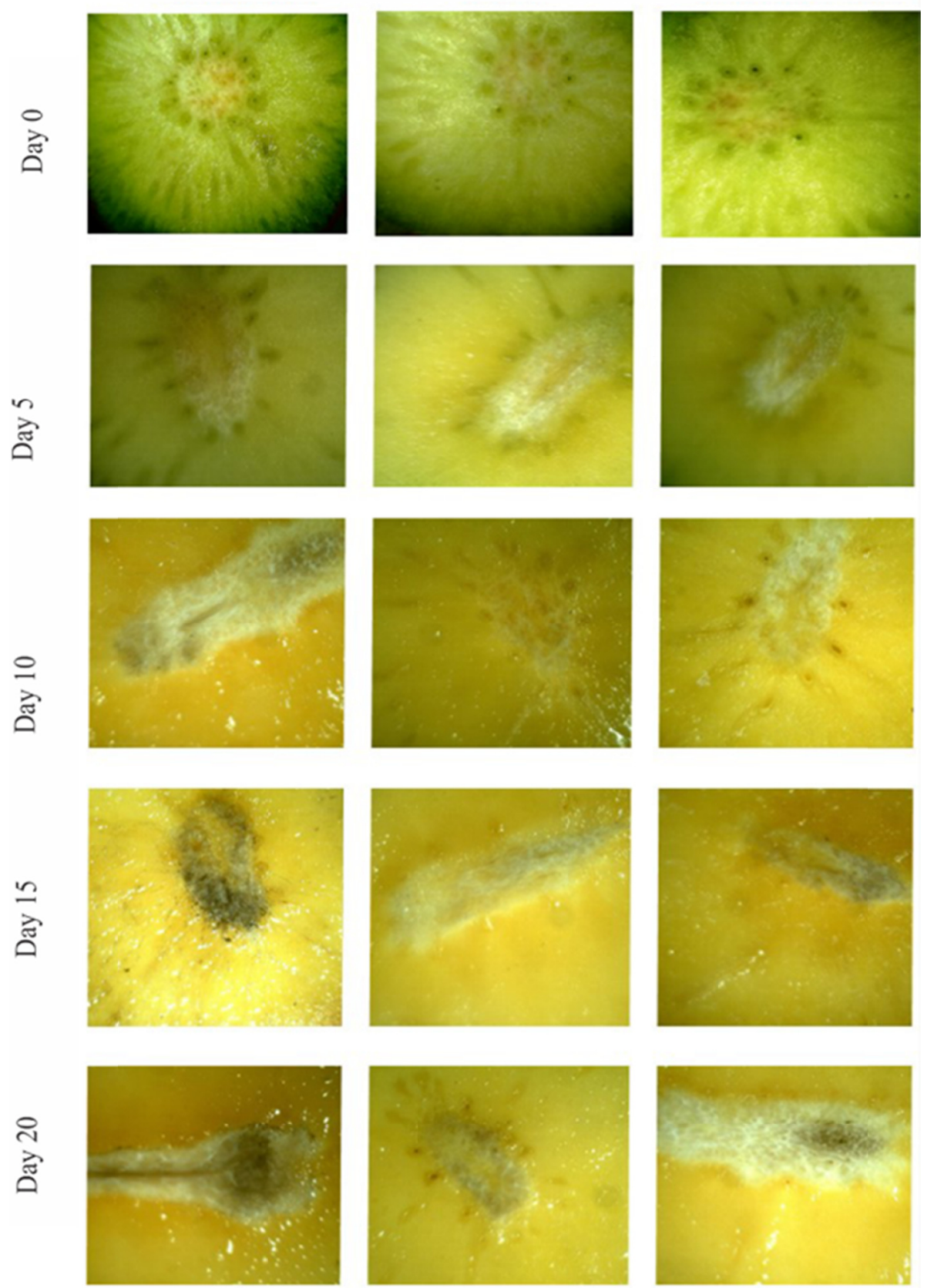

Figure 3. Internal growth of fungi of the genus Alternaria sp. in mango fruits subjected to three treatments (control, ozone, and chlorine dioxide) during 20 days of storage

Through statistical analysis, we observed that the application of a sanitizing substance, both ozone and chlorine dioxide, promotes growth retardation and fungal development compared to the control (Table 1). 
Table 1. Statistical evaluation of the growth of fungi of the genus Alternaria sp. on 'Palmer' mango fruits in three treatments: control, ozone, and chlorine dioxide. Numbers represent the average of the growth scores

\begin{tabular}{llllll}
\hline \multirow{2}{*}{ Treatment } & \multicolumn{5}{c}{ Days after inoculation } \\
\cline { 2 - 6 } & 0 & 5 & 10 & 15 & 20 \\
\hline Control & $0 \mathrm{cA}$ & $0.8 \mathrm{cA}$ & $1.6 \mathrm{bA}$ & $2.6 \mathrm{aA}$ & $2.8 \mathrm{aA}$ \\
Ozone & $0 \mathrm{cA}$ & $0 \mathrm{cC}$ & $0.4 \mathrm{bB}$ & $0.6 \mathrm{bB}$ & $1.2 \mathrm{aB}$ \\
Chlorine dioxide & $0 \mathrm{cA}$ & $0.2 \mathrm{cB}$ & $0.6 \mathrm{bB}$ & $1.2 \mathrm{aC}$ & $1.6 \mathrm{aB}$ \\
\hline
\end{tabular}

Note. * Means followed by the same lowercase letter in the row and uppercase in the column do not differ between the second Tukey test and 5\% probability.

Fruits treated with ozone did not show internal development of fungi during the evaluation period, unlike fruits treated with chlorine dioxide, which showed internal microbial growth on the 20th day of evaluation. Its efficiency may have been compromised by the presence of organic residues in the washing water. This is because, although they are powerful antimicrobial agents, the effectiveness of chlorine-based products can be compromised over time in the presence of organic matter (Keskinen et al., 2009; Shen et al., 2013; Mathew et al., 2018).

Monaco et al. (2016) found similar results. In an experiment with 'Palmer' mango, the authors observed that both ozonated and chlorinated water were efficient in eliminating the microorganisms they analyzed.

The percentage of mass loss (Figure 4) showed a gradual increase in all treatments. When evaluating the treatments separately, we noted greater losses for untreated fruits, followed by fruits treated with ozone, reaching loss values of $8.52 \%$ and $8.33 \%$ at the 20th day of storage, respectively. In contrast, chlorine dioxide-treated fruits had less weight loss in all evaluated intervals, reaching a maximum loss of $6.69 \%$.

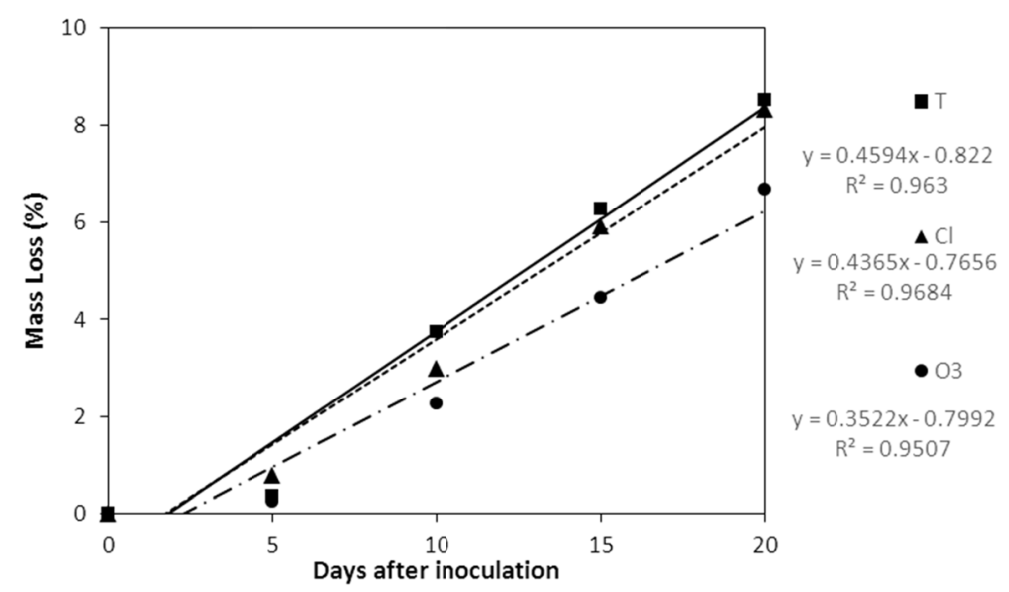

Figure 4. Mass loss (\%) of mango fruits submitted to inoculation with Alternaria sp. during storage and subjected to sanitizing treatments: $\mathrm{C}$ : control; O3: treatment with ozonated water at $3 \mathrm{ppm}$; and $\mathrm{Cl}$ : treatment with chlorine dioxide at $12 \mathrm{ppm}$

When analyzing the treatment factor separately (Table 2), it was found that the chlorine use provided less mass loss over the twenty storage days.

This result is in agreement with Zhang et al. (2019), who observed that control mangoes had a mass loss greater than that of the group treated with chlorine dioxide after 21 days of storage, and with Ferreira et al. (2017), who observed less fresh mass loss for ozonized strawberries compared to fruits subjected to sanitization with organic chlorine. 
Table 2. Statistical evaluation of the growth of fungi of the genus Alternaria sp. on 'Palmer' mango fruits in three treatments: control, ozone, and chlorine dioxide.

\begin{tabular}{llllll}
\hline \multirow{2}{*}{ Treatment } & \multicolumn{5}{c}{ Days after inoculation } \\
\cline { 2 - 6 } & 5 & 10 & 15 & 20 & Average \\
\hline Control & 0.35 & 2.97 & 5.93 & 8.33 & $4.31 \mathrm{~A}$ \\
Ozone & 0.40 & 2.60 & 5.23 & 7.50 & $3.83 \mathrm{AB}$ \\
Chlorine dioxide & 0.29 & 2.25 & 4.46 & 6.69 & $3.35 \mathrm{~B}$ \\
\hline
\end{tabular}

In addition, fruit firmness (Figure 5), an important parameter because it is one of the main characteristics of post-harvest quality that the microbial action can influence, showed a marked decrease in untreated fruits after the $5^{\text {th }}$ day of storage, maintaining values close to $12 \mathrm{~N}$ until the end of the experimental period. However, analyzing only the treatment factor in isolation, no significant difference was identified between the mean values (Table 3 ).

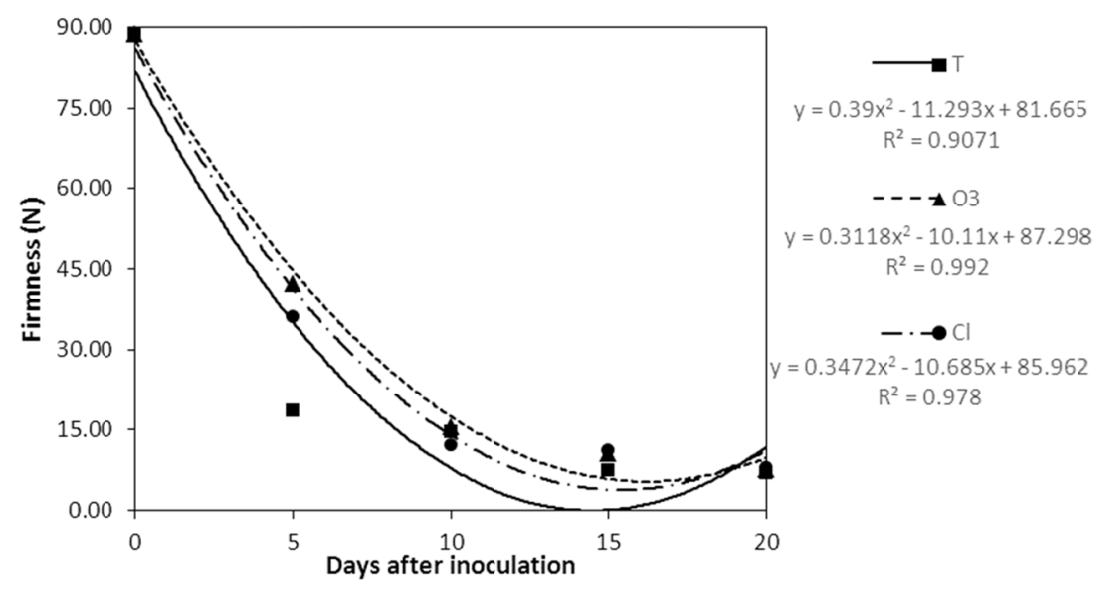

Figure 5. Firmness (N) of mango fruits subjected to inoculation of Alternaria sp. during storage and submitted to sanitizing treatment: T: control; O3: treatment with ozonated water at 3 ppm; and $\mathrm{Cl}$ : treatment with chlorine dioxide at $12 \mathrm{ppm}$

Treated fruits obtained a greater stability and consequently a longer shelf life regardless of the sanitizer applied. Other authors (Andrade-Cuvi et al., 2018) also found that treatments with ozone-based sanitizer delayed the loss of firmness of Solanum quitoense Lam. fruits for seven days.

Monaco et al. (2016) and Tran et al. (2013) found different results: the sanitizing action of ozone, even if it is an oxidizing agent, did not interfere with fruit firmness.

Table 3. Statistical evaluation of the fruit firmness (N) subjected to inoculation of Alternaria sp. on 'Palmer' mango fruits in three treatments: control, ozone, and chlorine dioxide

\begin{tabular}{lllllll}
\hline \multirow{2}{*}{ Treatment } & \multicolumn{7}{c}{ Days after inoculation } \\
\cline { 2 - 7 } & 0 & 5 & 10 & 15 & 20 & Average \\
\hline Control & 88.78 & 18.40 & 14.66 & 7.32 & 6.98 & $27.23 \mathrm{~A}$ \\
Ozone & 88.78 & 42.15 & 15.65 & 10.50 & 7.75 & $32.97 \mathrm{~A}$ \\
Chlorine dioxide & 88.78 & 36.15 & 12.12 & 11.18 & 7.77 & $31.20 \mathrm{~A}$ \\
\hline
\end{tabular}

As for the color of the skin (Table 4), there is a greater variation for the variable ' $b$ ' after the $10^{\text {th }}$ day of storage, when the fungal development was more advanced. The fruits treated with ozone obtained better averages. On the other hand, there was a decrease and a subsequent increase in luminosity levels (L) for both treatments, with statistically identical averages at the end of the $20^{\text {th }}$ day of evaluation. 
Table 4. Means for the color of the skin of fruits inoculated with Alternaria sp. and treated with Ozone $\left(\mathrm{O}_{3}\right)$, Chlorine Dioxide $\left(\mathrm{ClO}_{2}\right)$ and without treatment (Control) during storage. Reflectance values indicate luminance index (L), a* (index ranging from pure green, -100 , to pure yellow, 100), and $b^{*}$ (index ranging from pure blue, -100 , to pure red, 100)

\begin{tabular}{|c|c|c|c|c|c|c|}
\hline \multirow{2}{*}{ Parameter } & \multirow{2}{*}{ Treatment } & \multicolumn{5}{|c|}{ Days after inoculation } \\
\hline & & 0 & 5 & 10 & 15 & 20 \\
\hline \multirow{3}{*}{$\mathrm{L}$} & Control & $62.86 \mathrm{aA}$ & $36.65 \mathrm{cA}$ & $42.13 \mathrm{cA}$ & $29.11 \mathrm{cB}$ & $51.40 \mathrm{bA}$ \\
\hline & $\mathrm{O}_{3}$ & $68.71 \mathrm{aA}$ & $37.78 \mathrm{cA}$ & $46.63 \mathrm{bA}$ & $27.05 \mathrm{~dB}$ & $52.70 \mathrm{bA}$ \\
\hline & $\mathrm{ClO}_{2}$ & $70.26 \mathrm{aA}$ & $40.83 \mathrm{cB}$ & $40.37 \mathrm{cA}$ & $39.58 \mathrm{cA}$ & $52.23 \mathrm{bA}$ \\
\hline \multirow{3}{*}{$\mathrm{a}$} & Control & $3.46 \mathrm{aA}$ & $7.73 \mathrm{aA}$ & $9.59 \mathrm{aA}$ & $6.06 \mathrm{aA}$ & $14.40 \mathrm{aA}$ \\
\hline & $\mathrm{O}_{3}$ & $-1.96 \mathrm{bA}$ & $5.77 \mathrm{abA}$ & $14.18 \mathrm{abA}$ & $6.97 \mathrm{abA}$ & $20.13 \mathrm{aA}$ \\
\hline & $\mathrm{ClO}_{2}$ & $-0.48 \mathrm{bA}$ & $7.79 \mathrm{abA}$ & $17.68 \mathrm{aA}$ & $16.37 \mathrm{abA}$ & $17.64 \mathrm{aA}$ \\
\hline \multirow{3}{*}{$\mathrm{b}$} & Control & $24.39 \mathrm{aA}$ & $44.90 \mathrm{dA}$ & $58.11 \mathrm{bcAB}$ & $14.63 \mathrm{cdA}$ & $12.86 \mathrm{bA}$ \\
\hline & $\mathrm{O}_{3}$ & $20.94 \mathrm{aB}$ & $30.05 \mathrm{bA}$ & $37.60 \mathrm{aA}$ & $27.17 \mathrm{bA}$ & $20.80 \mathrm{aA}$ \\
\hline & $\mathrm{ClO}_{2}$ & $16.40 \mathrm{aB}$ & $25.38 \mathrm{cA}$ & $38.46 \mathrm{cB}$ & $42.44 \mathrm{cA}$ & $42.13 \mathrm{bA}$ \\
\hline
\end{tabular}

Note. * Means followed by the same lowercase letter in the row and uppercase in the column do not differ between the second Tukey test and $5 \%$ probability.

Tran et al. (2013) observed a $\mathrm{L}^{*}$ and $\mathrm{b}^{*}$ values decrease in mango fruits skin, treated with ozone. The same treatment reduced the flesh $\mathrm{a}^{*}$ value.

Likewise, the results for flesh color are shown in Table 5. The main difference for the flesh color parameter was in relation to the variable a, which determines the variation between green and yellow tones. There was an increase in the shade of yellow and a reduction in green for both treatments. In addition, ozone-treated fruits remained at higher values throughout the evaluation period, showing a probable ripening effect on the color of the flesh.

Table 5. Means for the flesh color of fruits inoculated with Alternaria sp. and treated with Ozone $\left(\mathrm{O}_{3}\right)$, Chlorine Dioxide $\left(\mathrm{ClO}_{2}\right)$ and without treatment (Control) during storage. Reflectance values indicate luminance index (L), $a^{*}$ (index ranging from pure green, -100 , to pure yellow, 100), and $b^{*}$ (index ranging from pure blue, -100 , to pure red, 100)

\begin{tabular}{|c|c|c|c|c|c|c|}
\hline \multirow{2}{*}{ Parameter } & \multirow{2}{*}{ Treatment } & \multicolumn{5}{|c|}{ Days after inoculation } \\
\hline & & 0 & 5 & 10 & 15 & 20 \\
\hline \multirow{3}{*}{$\mathrm{L}$} & Control & $68.71 \mathrm{aA}$ & $49.92 \mathrm{bA}$ & $56.61 \mathrm{bA}$ & $58.63 \mathrm{abA}$ & $49.77 \mathrm{bA}$ \\
\hline & $\mathrm{O}_{3}$ & $70.26 \mathrm{aA}$ & $50.64 \mathrm{cA}$ & $57.39 \mathrm{bcA}$ & $60.26 \mathrm{abA}$ & $48.34 \mathrm{cA}$ \\
\hline & $\mathrm{ClO}_{2}$ & $62.86 \mathrm{aA}$ & $37.62 \mathrm{~dB}$ & $55.79 \mathrm{cA}$ & $61.65 \mathrm{abA}$ & $50.78 \mathrm{cA}$ \\
\hline \multirow{3}{*}{$\mathrm{a}$} & Control & $-1.96 \mathrm{bA}$ & $4.20 \mathrm{abA}$ & $9.00 \mathrm{aA}$ & $7.55 \mathrm{aAB}$ & $4.41 \mathrm{abA}$ \\
\hline & $\mathrm{O}_{3}$ & $-0.48 \mathrm{cA}$ & $5.02 \mathrm{bcA}$ & $9.91 \mathrm{abA}$ & $12.71 \mathrm{aA}$ & $6.47 \mathrm{abcA}$ \\
\hline & $\mathrm{ClO}_{2}$ & $3.46 \mathrm{bA}$ & $8.28 \mathrm{aA}$ & $8.82 \mathrm{aA}$ & $4.46 \mathrm{abB}$ & $5.74 \mathrm{abA}$ \\
\hline \multirow{3}{*}{$b^{n s}$} & Control & 46.45 & 46.05 & 54.02 & 51.81 & 59.19 \\
\hline & $\mathrm{O}_{3}$ & 58.91 & 59.64 & 54.25 & 56.68 & 63.49 \\
\hline & $\mathrm{ClO}_{3}$ & 63.29 & 64.72 & 54.46 & 58.48 & 63.92 \\
\hline
\end{tabular}

Note. * Means followed by the same lowercase letter in the row and uppercase in the column do not differ according to the Tukey test at $5 \%$ probability.

${ }^{n s}$ Not significant for the Tukey test at 5\% probability.

There was an increase in the yellow shade and a decrease in green shade for both treatments. In addition, ozone-treated fruits remained at higher values than chlorine dioxide-treated fruits throughout the evaluation period, showing a probable ripening effect on flesh color. Mathew et al. (2019) found that prolonged washing 
with chlorine dioxide can react with phytochemicals in fruits and vegetables and, therefore, affect their appearance, causing darkening and loss of visual quality of fruits.

As for the contents of soluble solids (Figure 6), there were no significant differences for any treatment. Both treatments showed a significant increase on the 5 th day of storage, with a peak at $13.5^{\circ} \mathrm{Brix}$ at the 15 th day of storage for fruits treated with ozone and $15.4{ }^{\circ}$ Brix for fruits treated with chlorine dioxide.

Monaco et al. (2016) observed an increase in ripeness and consequently in soluble solids contents in an experiment using mangoes regardless of the treatment.

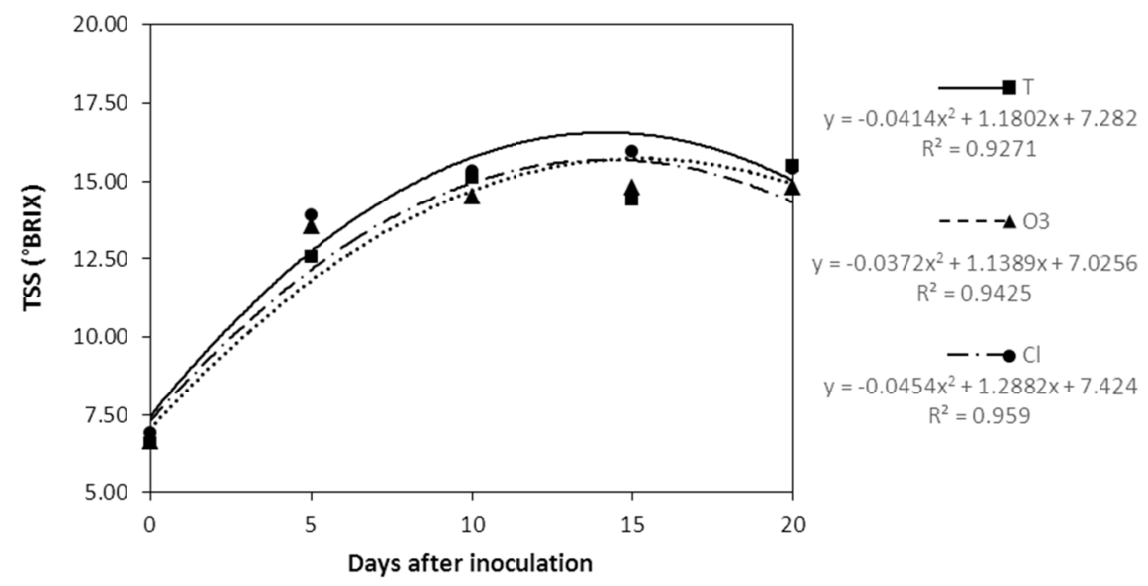

Figure 6. Total soluble solids contents TSS ( ${ }^{\circ}$ BRIX) of mango fruits subjected to inoculation of Alternaria sp. during storage and submitted to sanitizing treatment: T: control, O3: treatment with ozonated water at $3 \mathrm{ppm}$, and $\mathrm{Cl}$ : treatment with chlorine dioxide at $12 \mathrm{ppm}$

There was no statistically significant difference for the treatment factor, separately (Table 6), leading to the conclusion that sanitizing treatments do not alter the TSS. This result is positive, because one of the objectives of sanitizing treatment is to maintain the fruits post-harvest quality throughout storage.

Table 6. Total soluble solids contents TSS ( ${ }^{\circ}$ BRIX) and Total titratable acidity TTA ( $\mathrm{g}$ of citric acid $/ \mathrm{mL}$ of juice) of mango fruits subjected to inoculation of Alternaria sp. during storage and submitted to sanitizing treatment

\begin{tabular}{|c|c|c|c|c|c|c|}
\hline \multirow{2}{*}{ Treatment } & \multicolumn{6}{|c|}{ Days after inoculation } \\
\hline & 0 & 5 & 10 & 15 & 20 & Average \\
\hline \multicolumn{7}{|c|}{ Total soluble solids $\left({ }^{\circ} B R I X\right)$} \\
\hline Control & 6.57 & 15.10 & 13.57 & 15.50 & 11.33 & $12.41 \mathrm{~A}$ \\
\hline Ozone & 6.57 & 13.57 & 14.80 & 15.23 & 12.77 & $12.45 \mathrm{~A}$ \\
\hline Chlorine dioxide & 6.57 & 13.93 & 15.93 & 14.53 & 14.37 & $13.41 \mathrm{~A}$ \\
\hline \multicolumn{7}{|c|}{ Total titratable acidity TTA ( $g$ of citric acid $/ m L$ of juice) } \\
\hline Control & 0.79 & 0.18 & 0.17 & 0.15 & 0.11 & $0.28 \mathrm{~A}$ \\
\hline Ozone & 0.81 & 0.50 & 0.25 & 0.14 & 0.12 & $0.36 \mathrm{~A}$ \\
\hline Chlorine dioxide & 0.77 & 0.44 & 0.23 & 0.14 & 0.12 & $0.34 \mathrm{~A}$ \\
\hline
\end{tabular}

On the other hand, the variation in acidity levels of fruits (Figure 7) was noticeable, showing significant differences in both treatments. Ozone-treated fruits at $3 \mathrm{ppm}$ maintained high levels of acidity throughout the cycle, reaching a minimum of $0.12 \mathrm{~g}$ of citric $\mathrm{acid} / \mathrm{mL}$ of juice. 


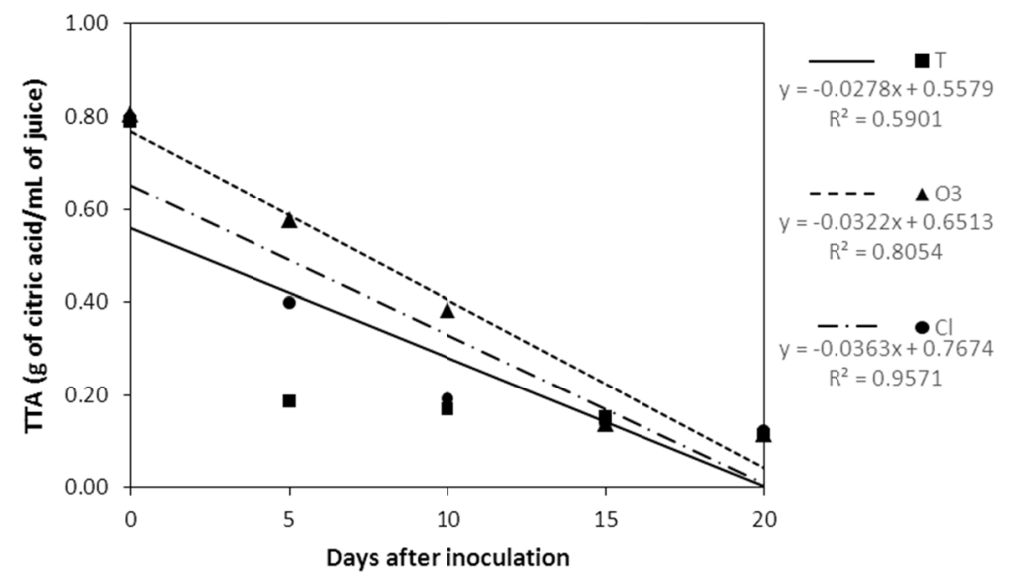

Figure 7. Total titratable acidity TTA ( $\mathrm{g}$ of citric acid/mL of juice) of mango fruits subjected to inoculation with Alternaria sp. during storage and submitted to sanitizing treatment: T: control, O3: treatment with ozonated water at $3 \mathrm{ppm}$, and $\mathrm{Cl}$ : treatment with chlorine dioxide at $12 \mathrm{ppm}$

In contrast, fruits treated with chlorine dioxide reduced the levels of TTA to a minimum of $0.18 \mathrm{~g}$ of citric $\mathrm{acid} / \mathrm{mL}$ of juice on the 10th day, whereas fruits treated with ozone only reached this index on around the 15 th day of evaluation, evidencing a more accelerated maturation process for the material treated with chlorine dioxide. Untreated fruits maintained low TTA rates throughout the evaluation period.

ANDRADE-CUVI et al. (2018) noticed a lower TTA in treated fruits compared to the control at the beginning of storage (day 0), and a decrease in TTA up to the 21st day at greater proportion for the control.

The sanitizing treatments did not alter the TTA (Table 6), which allows us to infer that the use of these substances allows fungal control without affecting the fruit organoleptic characteristics.

\section{Conclusions}

The methods of conservation with ozone and chlorine dioxide proved efficient in the conservation of fruits. They reduce mass loss and prolong shelf life through the best color indexes, $\mathrm{AD}$, soluble solids, and acidity.

The treatments satisfactorily inhibited the development of fungi of the genus Alternaria sp. compared to the control.

The treatment with chlorine dioxide shows a significant efficiency in the control of penetration of fungi of the genus Alternaria sp. inside the fruits, but with less efficiency than that of the treatment with ozone.

The sanitizing treatments did not alter TSS and ATT, allowing fungal control without affecting the organoleptic characteristics of the fruits.

\section{Acknowledgements}

To the Fundação de Amparo à Pesquisa do estado da Bahia for research funding and to Special Fruit and GrandValle farms.

\section{References}

Andrade-Cuvi, M., Guijarro-Fuertes, M., Jara-Gómez, S., Narváez-López, P., \& Moreno-Guerrero, C. Y. (2018). Concellón, A. Efecto del tratamiento con ozono gaseoso sobre la calidad fisicoquímica y capacidad antioxidante de naranjilla (Solanum quitoense Lam.). Revista Iberoamericana de Tecnología Postcosecha, $19(2)$.

Carletti, L., Botondi, R., Moscetti, R., Stella, E., Monarca, D., Cecchini, M., \& Massantini, R. (2013). Use of ozone in sanitation and storage of fresh fruits and vegetables. Journal of Food Agriculture and Environment, 11(3), 585-589.

Contreras-Soto, M. B., Medrano-Félix, A., Valdez-Torres, B., Chaidez, C., \& Castro-Del-Campo, N. (2019). Chlorine dioxide: An evaluation based on a microbial decay approach during mango packing process. International Journal of Environmental Health Research, 30(2). https://doi.org/10.1080/09603123.2019. 1670785 
Ferreira, W. F. S., Alencar, E. R., Alves, H., Ribeiro, J. L., \& Silva, C. R. (2017). Influence of pH on the efficacy of ozonated water to control microorganisms and its effect on the quality of stored strawberries (Fragaria $\times$ ananassa Duch.). Ciência e Agrotecnologia, 41(6). https://doi.org/10.1590/1413-70542017416013317

Glowacz, M., \& Rees, D. (2016). The practicality of using ozone with fruit and vegetables. Journal of the Science of Food and Agriculture, 96(14), 4637-4643. https://doi.org/10.1002/jsfa.7763

Horvitz, S., \& Cantalejo, M. J. (2014). Application of ozone for the postharvest treatment of fruits and vegetables. Critical Reviews in Food Science and Nutrition, 54(3), 312-39. https://doi.org/10.1080/ 10408398.2011.584353

Mathew, E. N., Muyyarikkandy, M. S., Bedell, C., \& Amalaradjou, M. A. (2018). Efficacy of Chlorine, Chlorine Dioxide, and Peroxyacetic Acid in Reducing Salmonella Contamination in Wash Water and on Mangoes Under Simulated Mango Packinghouse Washing Operations. Frontiers in Sustainable Food Systems, 2, 18. https://doi.org/10.3389/fsufs.2018.00018

Monaco, K. A., Costa, S. M., Minatel, I. O., Correa, C. R., Calero, F. A., Vianello, F., \& Lima, G. P. P. (2016). Influence of ozonated water sanitation on postharvest quality of conventionally and organically cultivated mangoes after postharvest storage. Postharvest Biology and Technology, 120, 69-75. https://doi.org/ 10.1016/j.postharvbio.2016.05.003

Noferini, M., Fiori, G., \& Costa, G. (2009). Un nuovo índice di maturazione per stabilire la raccolta ed orientare Il consumatore verso la qualità. Revista Frutticoltura, 7/8, 30-37.

Oliveira, E. S., Viana, F. M. P., \& Martins, M. V. V. (2016). Alternativas a fungicidas sintéticos no controle da antracnose da banana. Summa Phytopathol., 42(4), 340-350. https://doi.org/10.1590/0100-5405/2000

Ong, M. K., Ali, A., \& Kazi, F. K. (2013). Effect of gaseous ozone exposure on the control of colletotrichum gloeosporioides of papaya during ambient storage. Acta Horticulturae, 1012, 727-734. https://doi.org/ 10.17660/ActaHortic.2013.1012.97

Praeger, U., Herppich, W. B., \& Hassenberg, K. (2018). Aqueous chlorine dioxide treatment of horticultural produce: Effects on microbial safety and produce quality-A review. Critical Reviews in Food Science and Nutrition, 58(2), 318-333. https://doi.org/10.1080/10408398.2016.1169157

Tran, T. T. L., Aimla, S., Srilaong, V., Jitareerat, P., Wongs, C., \& Uthairatanakij, A. (2013). Fumigation with ozone to extend the storage life of mango fruit cv Nam Dok Mai No. 4. Agricultural Science Journal, 44(2), 663-672.

Vidal, M. F., \& Ximenes, L. J. F. (2016). Comportamento recente da fruticultura nordestina: Área, valor da produção e comercialização. Caderno Setorial ETENE, 1(2).

Zhang, B., Huang, C., \& Zhang, L. (2019). Application of antibacterial films for sustained release of chlorine dioxide microcapsules to preserve mangoes. Journal of Food Science and Technology, 56(3), 1095-1103. https://doi.org/10.1007/s13197-019-03636-6

\section{Copyrights}

Copyright for this article is retained by the author(s), with first publication rights granted to the journal.

This is an open-access article distributed under the terms and conditions of the Creative Commons Attribution license (http://creativecommons.org/licenses/by/4.0/). 